Max-Planck-Institut für demografische Forschung

Max Planck Institute for Demographic Research

Konrad-Zuse-Strasse 1 - D-18057 Rostock · GERMANY

Tel +49 (0) 3812081 - 0; Fax +49 (0) 3812081 - 202;

http://www.demogr.mpg.de

MPIDR WORKING PAPER WP 2005-016

JUNE 2005

\title{
Social capital related to fertility: theoretical foundations and empirical evidence from Bulgaria
}

Christoph Bühler (buehler@ demogr.mpg.de)

Dimiter Philipov (dimiter.philipov@oeaw.ac.at)

This working paper has been approved for release by: Vladimir M. Shkolnikov (shkolnikov@demogr.mpg.de), Head of the Laboratory for Demographic Data.

(C) Copyright is held by the authors.

Working papers of the Max Planck Institute for Demographic Research receive only limited review. Views or opinions expressed in working papers are attributable to the authors and do not necessarily reflect those of the Institute. 


\title{
Social capital related to fertility: theoretical foundations and empirical evidence from Bulgaria*
}

\author{
Christoph Bühler \\ and \\ Dimiter Philipov
}

Rostock and Vienna, June 2005

\author{
Christoph Bühler \\ (corresponding author) \\ Max-Planck-Institut für demografische Forschung \\ Konrad-Zuse-Str. 1, 18057 Rostock \\ Tel.: ++49 381/2081-174, Fax.: ++49 381/2081-474 \\ E-Mail: buehler@demogr.mpg.de \\ Dimiter Philipov \\ Institut für Demographie \\ Prinz Eugen-Str. 8 \\ 1040 Wien \\ E-Mail: dimiter.philipov@oeaw.ac.at
}

* This working paper is a translated and completely revised version of the working paper WP-2004024 by Christoph Bühler and Dimiter Philipov: "Zur Bedeutung sozialen Kapitals für Fertilitätsentscheidungen. Theoretische und empirische Darstellungen am Beispiel Bulgariens“". Max Planck Institute for Demographic Research, Rostock, 2004.

An earlier version of this paper was presented at the conference 'Sozialkapital: Grundlagen, Modelle und Anwendungen', Swiss Federal Institute of Technology (ETH), Zurich, Switzerland, July 2004. 


\begin{abstract}
Interpersonal relationships of support have been found to be an important factor in individual fertility intentions in Central and Eastern European countries. The foundations of this positive influence have not been well explored to date, however. We present a theoretical discussion on exchange-based social capital and argue that processes of interpersonal exchange are relevant for reproductive decisions when they provide access to resources that help to reduce the costs of having children and stabilize the economic situation of a household. Data from 2002 on the fertility intentions of 2,016 Bulgarian women support our argument. The availability of important and substantive resources has a positive impact on women's intentions to have a second or third child and their timing of having a first or second child. The embededness in kin-based exchange systems of indirect reciprocity shows similar positive effects and highlights especially the significance of parents as a source of intergenerational transfers and support.
\end{abstract}

Keywords: Social capital, fertility intentions, fertility in Bulgaria, exchange theory, reciprocity 


\section{Introduction}

Personal networks receive increasing recognition as explanatory factors of demographic events. A multitude of publications shows that, for example, supportive personal relationships improve individual health and longevity (Srezer and Woolcock 2004; Hawe and Shiell 2000; Kawachi et al. 1997) and influence pregnancies as well as the physical condition of the new-born in a positive way (Buka et al. 2003; Martín and Jiménez 2001; Pevalin et al. 2001). The consideration of social networks also improves the understanding of migration. Kinship ties trigger chain-migrations following family members who have already migrated (Haug 2000; Palloni et al. 2001).

Communication networks are important for reproductive behavior and contraceptive use, as these networks transfer fertility-related information, experiences, or evaluations and create structures of interpersonal influence (Bühler and Kohler 2004; Kohler 2001; Casterline 2001; Kohler et al. 2002; Carley 2001; Montgomery et al. 2001; Valente et al. 1997; Entwisle et al. 1996; Burt 1982; Rogers and Kincaid 1981). However, personal networks are characterized also by exchanges of material and non-material resources such as money, goods, services, power, or the capacity to work. The question, therefore, arises whether personal networks influence fertility by exchange relationships, i.e. by ties that give individuals access to resources of their network partners. There is little research on this topic. Hank et al. (2003), for example, investigate the impact of informal child-care opportunities on fertility-related behavior. Recent studies using data from Russia, Poland, Hungary, and Bulgaria document the positive significance of supportive resources located in social networks, attributed as individual social capital, on fertility intentions (Philipov et al. 2004; Bühler and Fratzcak 2004; Philipov 2003; Philipov and Shkolnikov 2001). The purpose of these studies is to explore the relevance of social capital to fertility intentions and to establish the concept as a meaningful explanatory factor for reproductive behavior in Central and Eastern Europe. They do not discuss the theory of social capital and its application to fertility in detail, however. The present article intends to close this gap. First, it derives on the basis of a general theory of social capital the characteristics of personal networks that give individuals access to the resources located in their networks and studies the types of resources relevant for reproductive decisions. Then, it explores the empirical significance of these characteristics and resources by analyzing their impact on fertility intentions of Bulgarian women.

The theoretical argumentation starts with a short description of how the structural perspective of social networks provides additional insights into the current explanations of declining and persistent low levels of fertility in Central and Eastern Europe (Section 2). Next, the article presents a network-based definition of social capital and proposes that exchange relationships of direct and indirect reciprocity are the structural mechanisms that generate social capital. There follows a discussion on the content of fertility-related social capital, with the inference that resources that can be utilized for a variety of purposes build social capital that supports fertility in Central and Eastern European societies (Section 3). After a description of the sample and the variables used in the analyses (Section 4), ordinal logit regressions are performed to explore the impact of individual social capital and net- 
works' compositions by relationships of direct and indirect reciprocity on fertility intentions (Section 5). A concluding discussion in the final section completes the article.

\section{The relevance of social networks to reproductive behavior in Bulgaria}

Similar to most of the Central and Eastern European countries, Bulgaria's transition from a socialist to a democratic society is characterized by significant economic, political, and institutional transformations as well as by substantial changes as to the processes of family formation and fertility. The latter is documented by a dramatic decline in births and an increase both in cohabitation and out-of-wedlock childbearing. ${ }^{1}$ The mean age at birth rose by 1.6 years between 1993 and 2000; this compares to an increase in the mean age at first birth by 2 years within the same period. The Total Fertility Rate decreased from 1.9 in 1989 to a level of 1.2 in 2002. Tempo-adjusted fertility rates (Bongaarts and Feeney 1998) reveal a slightly higher fertility level and, like the observed rates, indicate a significant drop in fertility

Explanations for these fertility trends are usually provided in the framework of economic or cultural approaches. In Bulgaria, the decline in fertility went hand in hand with decreasing and persistent low levels of economic performance. The Gross Domestic Product (GDP) in 1997 was only 66\% of the GDP in 1989 and climbed until 2003 to a level of 80\%. Real wages fell significantly and were additionally reduced by a period of galloping inflation in the second half of the 1990s. Although the economy recovered during the last years, unemployment reached a new maximum of $17.9 \%$ in 2000 , though with a tendency to decrease in recent years. Under these circumstances, direct and indirect child costs have risen considerably and hence people have postponed childbirth or they have decided not to have another child.

The cultural approach perceives transformations in values and lifestyles as a causal factor behind the changes in reproductive behavior in Central and Eastern Europe, Bulgaria in particular (UNECE 2002). The emergence of new values, like individualism, self-realization, autonomy, or emancipation that accompanied the process of the second demographic transition in Western Europe (van de Kaa 1988) assumed prominence also in socialist Central and Eastern Europe. They influenced to some extent the development of fertility during that time, but it was only after the breakdowns of the old regimes that broad sections of the population were able to put these new values and lifestyles into practice.

The structural perspective of social networks offers insights into how economic and cultural aspects influence fertility decisions in Central and Eastern European countries on the individual level. It expands the examination of the economic situation of an actor or a household by informal economic activities and supportive relationships as strategies for coping and stabilizing one's economic circum-

\footnotetext{
${ }^{1}$ See Philipov and Dobritz (2003) for an overview of the trends in family formation and fertility in Central and Eastern Europe.
} 
stances. ${ }^{2}$ It also offers a realistic view on the change in fertility-related values by perceiving this transformation as an outcome of a diffusion process. As part of this process, interpersonal relationships are the channels by which individuals get to know and learn about new evaluations of fertility and the use of modern contraceptives. ${ }^{3}$ To date the relevance of communication networks on recent fertility trends in Bulgaria or other Central and Eastern European countries has not been explored to depth. There are no studies on the diffusion of modern values and its implication on reproductive behavior. However, several studies support the relevance of social capital in the form of supportive networks on fertility. Philipov et al. (2004) report about increasing tendencies of Bulgarian and Hungarian women to have a second child when they are embedded in supportive personal relationships. Philipov (2003) and Philipov and Shkolnikov (2001) document similar results for Russia. According to Bühler and Fratzcak (2004), the intentions of Polish men and women to have a second child increase with the size of their supportive networks and also the more parents, friends, and neighbors are involved in supportive exchange relationships.

\section{Fertility-related social capital}

\subsection{Social capital and relationships of reciprocal exchange}

To understand the mechanisms behind the positive effects of supportive social relationships on fertility intentions, one has to step into a general theory of social capital. According to the definitions provided by Bourdieu (1983), Flap (2002), Lin (2001), Astone et al. (1999), and Coleman (1990), social capital is an expression of the resources individual actors have access to through their personal relationships. This includes the resources the individuals are already utilizing as well as resources they know or expect to be able to use when needed. The resources become available through their primary network partners as these are the immediate providers of resources and the channels through which they obtain indirect access to resources of network members they are not directly tied to. The accessible resources can be very different in nature, like goods, information, money, the capacity to work, influence, power, or active help. However, only resources that support individuals in reaching their goals build their personal social capital (Emerson 1976).

To get direct and indirect access to the resources of network partners, individuals have to be embedded in relationships of reciprocal exchange (Astone et al. 1999; Coleman 1990; Bourdieu 1983; Emerson 1976). These exchange relationships may transfer real goods and services, but they may also be of symbolic content by swapping gifts or emblematic goods. The relationships' reciprocal character builds social capital. By transferring goods, services, or symbolic gifts to network partners, indi-

\footnotetext{
${ }^{2}$ Goodwin et al. (2001), Lokshin and Yemtsov (2001), Lokshin et al. (2000), Lonkila (1999, 1997), Dershem and Gzirishvili (1998), and Sik (1995) discuss this argument applied to Russia, Georgia, and Hungary.

${ }^{3}$ See for example Bongaarts and Watkins (1996) or Kohler et al. (2001) for elaborating the relevance of diffusion processes and communication networks for the increasing use of contraceptives in developing countries.
} 
viduals obtain the right to receive goods, services, or gifts from these particular or other network partners. Two kinds of reciprocity exist: a direct and an indirect one. Direct reciprocity characterizes dyads and rests on expectations of having a fair exchange (Homans 1972). Both relationship partners expect that the overall value of resources given and received becomes balanced over a shorter or longer period. If this is not the case, the relationship will be broken off. Ongoing processes of exchange alter the character of a relationship. It may become closer and more trustworthy, with the consequence that both relationship partners become more willing to exchange resources of higher amount and quality (Wellman 1992) and to accept a late or unspecified moment of re-establishing reciprocity. Groups and social networks consist of exchange relationships of direct and indirect reciprocity (Stegbauer 2002; Peterson 1993). In the case of indirect reciprocity, individuals are engaged in transfers with two different network partners. They provide resources to one network partner and receive resources from other ones. Both transfers do not have to take place at the same time, but may occur within a shorter or longer period. Indirect reciprocity may rest on norms (Gouldner 1960; Ekeh 1974), fixed exchange relationships (Bearman 1997; Ziegler 1990), individual or collective ideas of fairness (Yamagishi and Cook 1993), or altruism (Takahashi 2000). All these aspects ensure that individuals can expect to receive repayments for the resources they give to other network members.

In exchange relationships of direct and indirect reciprocity, individuals transact investments by providing resources to their relationship partners. This way they obtain access to resourceful network partners and influence their willingness to offer them resources of a particular amount and quality (Portes 1998). Exchange systems of indirect reciprocity have some advantages in comparison to direct reciprocal exchange. As to direct reciprocity, both relationship partners should be able to exchange equivalent resources within a particular period. Therefore, they need to have a mutual interest in the resources of the relationship partner (Peterson 1993: 576). Both conditions do not exist in the case of indirect reciprocity. Consequently, indirect reciprocal exchange is less limited and more flexible. Moreover, in providing one of their network partners with resources, individuals can enhance the willingness of two other network partners ore more to give their resources to the individuals. This increases the probability that individuals receive the resources they need. Systems of indirect reciprocity also generate credit-worthiness for their members (Ekeh 1974) by offering resources of network partners without advance concessions, but with the obligation of repayment when network partners need help. Relationships between family members and kin are characterized by indirect reciprocity (Nye 1979; Alt 1994; Mahrbach 1994) as they build long-term networks that enable interpersonal exchange. As a result, family members and kin are among the most important sources of supportive resources (see, for example, Diewald 1991; Petermann 2002; Wellman and Wortley 1990; Schulz 1996; Quarantelli 1960).

On the other hand, relationships of direct reciprocity enable intensive investments that provide access to resources of exceptional amount and quality, as in intimate relationships or between married couples. Investments of this kind cannot be made easily in indirect reciprocal exchange systems. 
Members of these systems can only indirectly influence potential providers of resources. They also have to direct their activities towards common opinions of fairness. As the purpose of indirect exchange is also to strengthen the internal solidarity of a network, there should not be too much of an inequality among the values of the exchanged goods and services.

These considerations lead to three conclusions about the nature of social capital and its empirical representation. First, social capital has an explicit prospective character. People decide to take a particular course of action based on the resources they expect to have access to. Knowledge about experienced transfers of resources within a particular period covers this aspect only in part, because it largely reflects past or current needs of the individuals or their network partners. If there were no needs, then people would not report interpersonal transfers. Consequently, social capital has to be measured by transfers experienced in the past as well as by future potential transfers to cover individuals' pools of network based resources. Second, social capital rests on reciprocal exchange relationships. People provide their network partners with resources in the expectation to receive resources. Therefore, information about both sides of the exchange process has to be collected: Potential and experienced transfers individuals receive from their network partners as well as those provided by them. Information about the latter aspect gives insights into investment activities and long-term exchange relationships. Finally, the amount and quality of resources that are available to individuals depend on their embeddedness in relationships of direct and indirect reciprocity. Exchange systems of indirect reciprocity give flexible access to different resources whereas close and long-term relationships of direct reciprocity provide access to resources high in amount and quality. Considering these two different kinds of reciprocal exchange offers the opportunity to obtain general information on an individuals' social capital, as they offer different opportunities of having access to different resources.

\subsection{Resources relevant for fertility}

Network-based resources build social capital if they support individuals to reach their goals, i.e. if they help to meet the costs of particular courses of action. This applies also to fertility-related decisions. Research on the value of children identifies a variety of costs of having children such as direct or indirect monetary costs, psychic strains, additional workload in the household, or changes in parent's personal relationships (see, for example, Brähler et al. 2001; Morgan and Berkowitz King 2001; Nauck 2001, 1989; Yamaguchi and Ferguson 1995; Bulatao 1981). Consequently, resources that might lower the costs of having children and that are available from social networks are of a different nature: monetary support to reduce the general costs of rearing a child (Bühler and Fratczak 2004) or to assure an education of a particular quality, leaving to or sharing with family members or kin a room, flat, or house (Hao 1995), informal child care arrangements (Hank et al. 2003; Parish et al. 1991; Hogan et al. 1990; Floge 1985), support to meet the basic needs of a family, like food (Bühler 
2004; Perelli 2004), help and support in household duties, or emotional support and advice when problems with the children arise.

Access to resources that are utilizable for a broad variety of needs, such as money, time, or capacity to work, may also play an important role in reproductive choices. Having children is associated with long-term costs and uncertainties that can hardly be calculated at the time the decision to have a child or not is taken. This holds especially in periods of rapid social and economic change during which decisions with significant and irreversible outcomes, like having children, are postponed or given up. Therefore, the embeddedness in social networks that provide broadly utilizable resources may support the decision to have a child, as these resources help to stabilize or improve the economic situation of an individual or a household (Philipov and Shkolnikov 2001). It can also add to personal stability and security due to the awareness that there is support available if needed. The effect of this kind of social capital on fertility thus is an indirect one. Similarly to monetary income, it improves the living conditions of the individuals and their ability to have children. Empirical research on the influence of social capital on fertility intentions in Central and Eastern primarily considers broadly utilizable social capital, by addressing individual access to non-monetary and monetary supportive resources in general (Philipov et al. 2004; Bühler and Fratzcak 2004; Philipov 2003; Philipov and Shkolnikov 2001).

Following the theoretical discussion presented above, the subsequent empirical analyses will explore the influence of individuals' embeddedness in exchange relationships, which provide resources that are utilizable for a broad variety of needs, on their reproductive intentions. These resources are small help, substantive and important support, and the opportunity to borrow money. To identify whether all resources or only particular ones generate fertility-related social capital, these resources are introduced separately to the analyses. The empirical investigations will also explore how much fertility related social capital is an expression of having access to resources or of investing in relationships that may provide support in future. Finally, the analyses will consider the number of direct and indirect reciprocal relationships in these networks to identify whether reciprocal exchange relationships in general or of particular reciprocity constitute fertility-related social capital.

\section{Data and variables}

\subsection{The sample}

The empirical analyses rest on data from the research project "The Impact of Social Capital and Coping Strategies on Reproductive and Marital Behavior", a panel survey carried out in Bulgaria under the responsibility of the Max Planck Institute for Demographic Research and the Bulgarian Academy of Sciences. The first wave was accomplished in Summer 2002 and the second wave will take place in Autumn 2005. The survey stresses the demographic events of leaving the parental home, marriage, 
and fertility. It also has a strong emphasis on explanatory factors, such as the economic situation of the household, coping strategies, the individual employment situations, the embeddedness in supportive and communicative networks, or the change of values and norms in the Bulgarian society.

As the survey concentrates on leaving home, partnership formation, and fertility, its population of male and female respondents is limited to age cohorts which usually experience these events. The survey's sample therefore consists of women aged 18 to 34, independent of their marital status. Male respondents are in the same age range if they are unmarried and do not live together with a partner. If they live together with a partner in a marriage or cohabitation, the age range is 18 to 66 . This is because in each case of a female respondent being married or cohabiting, the corresponding spouse or partner was automatically interviewed, too.

The sample was drawn in collaboration with the Bulgarian National Statistical Office, using individual information from the Bulgarian census in 2001. The realized survey population consists of 10,009 individuals and covers 5,765 married or cohabiting people and 4,244 single, divorced, or widowed persons. As the subsequent analyses investigate women's fertility related intentions, this population is limited to the 4,775 interviewed women. However, further restrictions have to be made to receive a meaningful population for analyses. The ethnic groups of Turks and Roma make a substantive part of the Bulgarian society; consequently, Turkish and Roma respondents represent $9.7 \%$ resp. $7.1 \%$ of the overall survey population. Explorative analyses show that fertility behavior and its determinants differ significantly between the ethnic groups and that these differences are only covered insufficiently in multivariate analyses by controlling for ethnicity. The population thus is restricted to 3,837 women who attribute themselves as belonging to the Bulgarian ethnicity. Furthermore, the analyses consider only women cohabiting or married at the time of interview. This restriction is made since measures of social capital are used as central explanatory variables. The size and composition of social networks is largely context-specific and changes significantly due to demographic events like marriage, the birth of a child, or divorce. It therefore does not make sense to consider unmarried women in the analyses. This is because they report personal networks that will change significantly once a union with a partner is formed and considerations to have a child have been made. As a result, the subsequent analyses do not provide information about the determinants of the fertility intentions of all Bulgarian women aged 18 to 34, but only for the subpopulation of married and cohabiting ones $(n=2,272)$. Finally, all women known to be infertile $(n=151)$ or pregnant $(n=105)$ at the time of the interview are excluded. The subsequent analyses start with a population of 2,016 female respondents.

\subsection{Fertility intentions as dependent variables}

The multivariate analyses use fertility intentions, instead of observed fertility outcomes, as dependent variables because of methodological as well as theoretical considerations. In order to identify a causal effect of social capital on reproductive behavior, data are needed that provide information about the characteristics of an individual's personal network at the time the decision to have a child is made. 
The cross-sectional data we use cannot offer this information. Moreover, a retrospective registration of social networks is of limited utility. Personal networks are primarily used within daily activities; therefore people remember their interpersonal transactions and interactions with increasing inaccuracy the more these activities are located in the past. Addressing fertility intentions as well as the characteristics of the social networks at the time of interview helps to solve this problem to some extent. The theoretical motivation rests on the fact that intentions form a central part in the theories of purposeful behavior (Aijzen 1991). People act in a goal-oriented manner, based on intentions. The causal relationship between intention and behavior is also considered in models of reproductive behavior (Morgan 2003; Quesnel-Vallée und Morgan 2003; Bongaarts 2002). The models show that the number of children born rests on a mother's intended number of children as well as on factors she cannot anticipate, like unintended pregnancies, child mortality, infertility, or unforeseeable opportunity costs. These intervening factors are responsible for the fact that fertility intentions and reproductive behavior only weakly match on the individual level (Schoen et al. 1997). However, reproductive behavior emerges from fertility-related intentions and therefore it is important to understand the determinants of this motivational component of fertility (Miller 1994).

As the number of children born is an outcome of a sequential decision making process, subsequent analyses are carried out for different subgroups defined by parity. To have a first or another child as well as the timing of birth is always a new decision that reflects a woman's general fertility intentions and aspects of her personal situation (Miller and Pasta 1995).

The survey addresses intentions related to the tempo and the quantum of fertility. The respondents were asked, first, whether they intend to have a first or another child within the next two years. Possible answers were 'definitely yes', 'probably yes', 'probably not', and 'definitely not'. A period of two years was chosen to receive information about concrete fertility intentions. If respondents replied 'probably not' or 'definitely not' to have a first or another child within the next two years, then a question was asked whether they intend ever to have a first or another child. The answers could be differentiated in the same way as in the previous question. The investigation of tempo-related intentions to have a first or another child is only meaningful for individuals that actually want to have this child. Therefore, only respondents that want to have ever a first or another child are considered for this variable. For the variable about the quantum related fertility intentions, all respondents that probably or definitely want to have a child within the next two years are coded as respondents that also definitely ever want to have the respective child (for more details on the tempo-quantum of fertility intentions, see Philipov et al. 2005).

Table 1 about here 


\subsection{Social capital}

Respondents' social capital was measured by the amount of experienced and potential transfers of resources. Respondents were asked about the size of three different networks that provide them with three different kinds of resources during the last two years: 'small help', 'substantial and important support', and 'borrowed money'. If the respondents reported that no network partners of a particular network provided them with the particular resource, they were asked to name the number of network partners from whom they would receive this resource if needed. For example, if a respondent replied that nobody provided 'substantial and important support', than the respondent was asked to name the number of network partners he or she could ask for this kind of support. For each of the three kinds of resources, the numbers of experienced and potential supportive network partners are summarized to three variables that provide information about the respondents' amount of social capital according to 'small help', 'substantial and important support', and 'borrowed money'. ${ }^{4}$ To cover the respondents' involvement in long-term exchange relationships and investments in social capital, they were also asked about the number of network partners to whom they provided 'important and substantive support'. If no network partner was named, the respondents were asked about the number of network partners that would ask them to provide this resource. These two variables are, again, summarized to a new one giving information about the number of network partners that receive 'important and substantive support' from the respondents.

The subsequent analyses consider a very simple property of social networks, namely, size. However, this structural characteristic is a central dimension of social capital (Bourdieu 1983; Flap 2002). The analyses address the processes of interpersonal exchange as the basic mechanism of generating social capital. Structural properties of social networks, such as density, cohesiveness, openness, or structural similarity, are very much outcomes of these processes and are not considered subsequently.

For a subgroup of network partners, the questionnaire collected personal characteristics and some attributes of the respondent's relationships with them. For example, when a respondent reported about network partners from whom he received 'important and substantive support', he was asked to select up to five network partners that were most important within this context. Next, he was asked for the network partners' gender, traveling distance between the respondent and them, their frequency of contact, and their role relationships, i.e. whether they belong to the respondent's family or whether they are relatives, friends, acquaintances, colleagues etc. The latter variable can be used as an indicator for the kind of reciprocity that characterizes the relationships. Members of the extended family and kin build systems of indirect reciprocal exchange. Relationships with the partner, friends, or colleagues rest on direct reciprocity. The same information was collected for up to five network partners

\footnotetext{
${ }^{4}$ If, for example, a respondent experienced 'substantive and important support' provided from her network partners, the number of these network partners represents her amount of social capital according to this resource. If she did not experience this kind of support, the number network partners that would provide her with 'impor-
} 
that lend money to the respondent and/or that received 'important and substantive support' from her. For the analyses, the network partners from these three different networks are pooled and their characteristics are aggregated. This is done to receive some independence between the composition of role relationships and the kind of resources received or given. Two new variables are created to indicate the number of indirect reciprocal relationships between the respondents and their network partners, measured by the number of extended family members and relatives, and to measure the number of direct reciprocal relationships, represented by the number of friends, colleagues, neighbors, and acquaintances. Husbands and partners are not considered, as the analyses concentrate on the exchange of resources with network partners outside the respondents' core family. To cover a probably significant role the respondents' direct parents may play in the relationships of indirect reciprocity, three additional variables are constructed. Two dummy variables that report whether the respondent named one or both direct parents and one variable about the number of indirect reciprocal relationships to all other relatives.

\subsection{Control variables}

Primarily for the purpose of control, the multivariate analyses consider the basic characteristics of the respondents, their husbands or partners, and their households. Husbands', partners', and households' characteristics are considered because we assume that women form their fertility intentions not solely based on their personal characteristics. The respondents are portrayed by age, the completed or aspired level of education, the employment situation, their religiosity, and the number of siblings they have. Husbands or partners are attributed with their age, the level of education completed or aspired, and their employment situation. As the analyses take the respondents' perspectives into account, they consider only the characteristics of husbands' or partners' that we assume most of the respondents to know accurately. However, information on these characteristics is taken from the husbands' or partners' interviews. The situation of the household is represented by its equivalence income, i.e. by the household members' per capita income weighted by the age structure of the household. ${ }^{5}$ Finally, one variable controls for the differences of fertility intentions between urban and rural areas.

\section{Empirical results}

The empirical results are presented in two steps. First, the distributions of the central variables in the analyses are reported: the respondents' fertility intentions and the size and composition of their ex-

\footnotetext{
tant and substantive support' represents her amount of social capital.

${ }^{5}$ Information about a household's income is covered by an ordinally scaled variable with the following categories: 'up to $100 \mathrm{Leva}$ ', '101 to $200 \mathrm{Leva}$ ', '201 to $300 \mathrm{Leva}^{\prime}$, '301 to $400 \mathrm{Leva}$ ', ' 401 to $600 \mathrm{Leva}$ ', '601 to 800 Leva', '801 to 1,000 Leva', and '1,001 Leva or more'. To calculate the equivalence income, the value of the center of each income interval is taken. As to the highest income category, a value of 1,200 Leva is set. The household size is weighted according to the modified OECD scale (Dennis and Guio 2004). The first adult is weighted with the factor 1.0. Every additional household member who is older than 13 years receives a weight of 0.5 . If he or she is aged 13 or younger, a weight of 0.3 is set.
} 
change networks. Next, estimates from ordered logistic regressions are discussed to explore the possible effects of the respondents' social capital and their embeddedness in relationships of direct and indirect reciprocity on their fertility intentions.

\subsection{Fertility intentions}

Of all women considered in the analyses, 35.9\% definitely intend to have a first or another child (see Table 2). This compares to $36.1 \%$ who perceive their reproductive period to be completed and for certain do not intend to give birth to a child. However, as expected, these intentions depend significantly on the actual number of children belonging to the respondent. Most of the childless respondents $(87.7 \%)$ intend to have at least one child for sure. However, this intention changes significantly in the case of a second child. Here, only $43.3 \%$ are certain that they want to have a second child whereas $37.4 \%$ intend to complete their reproductive period. Finally, among the respondents with two, three, or more children, only a marked minority that intends to have a further child can be identified.

Table 2 about here

As the results in Table 2 rest on respondents aged between 18 and 34, they document that the reproductive period of married or cohabiting Bulgarian women is located in an age interval of 20 to 30 . Consequently, the majority of the respondents who definitely or probably want to have a first or another child intends to have this child within the next two years (see Table 3). This holds especially for the timing of the first child. However, the intention to postpone the birth increases with parity.

Table 3 about here

The results in Tables 2 and 3 entail two limitations for the subsequent analyses. First, the distribution of the intentions of the childless women ever to have a first child is too skewed for a meaningful analysis (94.5\% definitely or probably intend to have a first child). Second, the number of respondents with three or more children $(n=40)$ as well as the number of respondents who probably or definitely intend to have a third $(n=50)$ or. a fourth or fifth one $(n=3)$ within the next two years are too small. Therefore, the multivariate analyses will only consider the respondents' intentions ever to have a second or a third child and their intentions to have a first or a second one within the next two years.

\subsection{The size and composition of networks}

The majority of the women reported to have access to the supportive resources that were addressed in the questionnaire. Of the respondents, only $6.0 \%$ resp. $7.7 \%$ replied not to know at least one network partner that provides 'small help' or 'important and substantive support' (see Table 4). 12.3\% do not know of network partners that lend money. $51.1 \%$ of the respondents borrowed money from their 
network partners in the last two years. This money was repeatedly spent on goods for basic needs, such as food, clothing, or medicine (62.1\%), but also on bills for heating and lighting (31.9\%), or on unexpected payments of a smaller amount (25.6\%), like repairs or small medical treatments (multiple answers were possible). The mean values of the size of the non-empty networks show that the respondents are able to reach on average 3.7 network partners when they need 'small help', followed by 2.7 persons that give 'substantive and important support', and 2.4 people that lend money to them. The results on the small networks agree with insights from other studies (see for example Bühler and Fratczak 2004, Pfenning 1995, or Bernard et al. 1990). Within the personal network, there is mostly only a small number of members able and willing to give substantive support. Of the respondents, $87.5 \%$ gave or would give 'important and substantive support' to 3.0 network partners on average. A cross tabulation of the respondents who received and/or gave this kind of resource documents that $50.2 \%$ of them were engaged in exchange processes, i.e. they received as well as provided 'important and substantive support' within the last two years.

Table 5 reports the networks' compositions by the relationships of indirect and direct reciprocity. ${ }^{6}$ Indirect reciprocal relationships form the majority. They make on average $55 \%$ of the relationships between the respondents and their network partners. On the one hand, this is caused by the significance of the respondents' direct parents (30\%), but also by parents-in-law, members of the extended family, and relatives (25\%). Direct parents are crucial providers of 'substantive and important support' and they are a valuable source of money, but they make also one fourth of the network partners that were supported by the respondents. Direct reciprocal relationships with friends, colleagues, neighbors, or acquaintances form a significant share of the respondents' exchange activities within the last two years as well. This group of network partners is the most important source for borrowed money (37\%) and they are also frequent beneficiaries of 'important and substantive support' given by the respondents. Furthermore, there are supportive relationships within the respondents' core families. Husbands or partners make on average $27 \%$ of the network partners that provided important support to the respondents and they form $22 \%$ of the network partners that received this kind of support.

Table 5 about here

\subsection{Multivariate Analyses}

The multivariate analyses first address the question whether social capital in general or whether having access to particular resources influence fertility intentions. Therefore, the sizes of the different networks are introduced in an ordinal logistic regression simultaneously controlling for the basic char-

\footnotetext{
${ }^{6}$ For a better comparison, Table 5 reports the mean proportions of indirect and direct reciprocal relationships and of the different groups of network partners. It also includes the group of husbands, partners, and children. However, the multivariate analyses consider the real numbers of the different relationships and groups of net-
} 
acteristics of the respondents, their husbands/partners, and their households.

The results in Table 6 document the general importance of 'substantive and important support' on the respondents' fertility intentions. The more the respondents have access to network partners who provide this resource, the more they are intending to have ever a second or a third child as well as to have a first or a second child within the next two years. The coefficients report a linear relationship according to the timing of birth. The respondents' intentions to have a first or a second child within the next two years benefit from each additional supportive network partner. However, this does not apply to the quantum related intentions. As the significant negative signs of the squared network size document, the respondents face a declining marginal utility of supportive network partners. Each additional network partner provides substantive and important support that is to some extent already provided by other network partners. Therefore, having access to a maximum of supportive network partners is not the optimal solution, but to know a reasonable number of them. As the data contain no detailed information about the kind of available support, no sound reason for these results can be given. However, a first interpretation is that the respondents' quantum and timing related fertility intentions benefit from different kinds of important support that can be provided best by different numbers of network partners.

Table 6 about here

The access to network partners who provide 'small help' in daily activities is of heterogeneous importance. There is no impact on the intention ever to have a second child whereas it supports the consideration to have a third one. It influences the respondents' intentions to have a second child within the next two years in a negative way. Thus, 'small help' from other people is not located around activities that are relevant for fertility intentions according to the first or second child. However, with the second child, the respondents' workload increases and consequently their intention to have a third one depends, among other things, on the availability of network partners that help them with their daily activities.

Having access to network partners that lend money does not have any effect on the respondents' fertility intentions. As the descriptive analyses show, money is primarily borrowed from other people to close short-term financial gaps. This result sheds light on the character of the resources that increase the respondents' fertility intentions. Resources that help to cope with daily or short-term problems tend to be of minor relevance. Fertility decisions are decisions with long term consequences; therefore, resources matter that substantively shape the respondents' living conditions and opportunities for activities.

The number of network partners that received or would receive 'substantive and important

work partners. See Table 1 for the descriptive statistics of these variables. 
support' from the respondent does not show any influence, too. This does not apply, however, when all variables about the respondents' access to network partners who provide support are excluded from the analyses (the results are not reported here in detail). In this case, the respondents' investments in social capital show significant positive influences on their intentions ever to have a second child or to have a first child within the next two years. Transfers of 'important and substantive support' to other network partners are used as indicators for long-term exchange relationships and investments in social capital. Nevertheless, these indirect measures of the past or future availability of supportive resources are not relevant as people adjust their fertility intentions directly to the resources they receive or would receive if they need them.

Although the characteristics of the respondents, their husbands/partners, and their households are primarily used as control variables, they document some interesting results that will be discussed selectively in the following. Women who intend to start education or who live in high income households plan to postpone the birth of a first child. It is shown somewhere else (Bühler 2005) that the latter effect is caused by an economically very successful group of respondents who belong to the highest 10 per cent quintile of the equivalence income distribution. They live in small households of mostly two persons with incomes far above average. The intention to have a second child and the timing of its birth is very much influenced by the age of the respondents' and of their husbands or partners. Women that had their first child by the age of 30 significantly intend to have a second child relative to the respondents aged 30 to 34 . However, these age groups also intend to postpone the birth of the second child. Women of age 30 to 34 and who intend to have a second child want to put their intention into practice within the next two years. The timing of the second child also depends significantly on the employment situation of the respondent. Compared to unemployed women, respondents that are in education or are not working intend to postpone the birth of the second child. The latter effect is primarily caused by women on parental leave. Finally, the results show some evidence that the economic situation of the household matters as far as the respondents' intention to have a third child is concerned. This is documented by the significant positive effect of the household's equivalence income.

In a second step, the analyses focus on the relevance of relationships of direct and indirect reciprocity. Two models are estimated (see Table 7). Model 1 considers the number of direct and indirect reciprocal relationships. Model 2 addresses the relevance of the respondents' direct parents among the number of relationships of indirect reciprocity. Both models consider the same set of control variables that is used for the estimates in Table 6. For a better presentation, however, only the effects of the variables that represent the direct and indirect reciprocal relationships are listed. The results document the significance of indirect reciprocal relationships for the respondents' fertility intensions. The more they reported about relationships with family members and kin, the more they intend to have a second 
child or to have a first or a second child within the next two years. According to the intended timing of the first or the second child, this effect is primarily caused by the direct parents of the respondents, as the results of Model 2 show. Nevertheless, in the context of the general intention to have a second child, other relatives exert some positive influence, too. Relationships of direct reciprocity to friends, colleagues, neighbors, or acquaintances have either a negative impact or show no relevance. Although this group of network partners is an important source for borrowed money, it does not provide resources for the respondents that influence their fertility intentions in a positive way.

Table 7 about here

\section{Concluding discussion}

Individuals do not live in isolation. They are embedded in social environments that influence their preferences and shape their opportunities to follow particular courses of action by providing valuable resources to them. Individuals are aware of these network-related resources and take them into account in their decisions and planning. The availability of these resources depends on their distribution within the social network as well as on the characters of individuals' personal relationships with network partners who posses or control them. Network partners are willing to give these resources on the basis of exchange relationships of direct and indirect reciprocity. Due to individuals' transfers of goods and services to network partners, they receive the right to be provided with resources from the same or other network partners if in need of them. Social relationships and social networks generate social capital on the basis of reciprocal exchange.

This general form of social capital can directly be applied to reproductive intentions and behavior. The decision to have a child is associated with long-term costs and uncertainties that significantly intervene in a household's economic situation and social structure. Thus, one can hypothesize that individuals intend to have a first or another child, if they perceive to possess or to have access to an amount of resources that is subjectively adequate to handle the expected emotional, economic, and social costs caused by the child. These resources can be acquired to some extent by personal relationships, i.e. by ongoing interpersonal exchange processes. The resources may be fertility specific, for example having access to informal child care possibilities, knowing people who help with the household, or who assist in case of problems with the children. However, they may also be of a multipurpose nature, for example in the form of money, time, influence, or active support. These resources influence fertility indirectly as they help to stabilize the economic and social situation of an individual or a household, which again has an impact on reproductive goals. This aspect applies to Bulgaria and to many other parts of Central and Eastern Europe because these countries still have to handle serious economic problems and cope with low levels of income for a wide range of their populations.

The empirical analyses address basic attributes of fertility-related social capital: different kinds of supportive resources, networks of giving and receiving support, and personal relationships that are 
characterized by direct or indirect reciprocal exchange. On the basis of survey data from Bulgarian women aged 18 to 34 , estimates from ordered logit regressions confirm the relevance of multipurpose social capital for fertility intentions, but they also document that only particular resources are relevant. Having access to network partners that provide 'important and substantive support' positively influences the quantum and the timing of fertility intentions. However, an increasing number of network partners that provide 'small help' in daily activities shows, with the exception of the intention to have a third child, a negative or no effect. Moreover, having access to borrowed money is not of any relevance. These results lead to the conclusion that women's fertility intentions do not depend on personal social capital that provides access to resources which make daily life easier, but on resources that may influence their personal situation substantially. Therefore, fertility-related social capital might be perceived as a kind of income that helps individuals to cope with their economic and social situation in general.

Investments in social capital or the existence of long-term exchange relationships, measured by the number of network partners that received or might receive support from the respondent show no effect on fertility intentions as soon as the number of network partners that provide supportive resources are considered in the analyses. People's behavioral intentions, therefore, rest on their perceptions of having access to the resources of other people more so than on the indirect view of their activities that ensure this access. However, subsequent analyses should clarify whether it is meaningful in general to consider investments in social capital within a theory that explains individual behavior as an outcome of social capital.

Individual relationships of indirect reciprocity also matter to fertility intentions. Relationships of direct reciprocity exert no influence or a negative one. Exchange relationships of indirect reciprocity provide flexible access to resources as they do not have to be repaid in the short-term and not directly to the network partners that provide them. The direct parents of the respondents are of high significance in this context. The question thus arises whether it is meaningful to use the complex theory and method of social capital when in the end they only identify intergenerational transfers and support. Note that the effects of indirect and direct reciprocal relationships largely reflect the resources that are transferred by these relationships. Direct parents are influential, because they are the primary source of 'important and substantive support'. Direct reciprocal relationships with friends, colleagues, or neighbors show a negative influence or no influence because they are important sources of borrowed money. Therefore, in answer to this objection, variables about direct and indirect reciprocal relationships are needed that are independent from the resources transferred. However, in the context of substantive support our results as well as findings from Poland (Bühler and Fratzcak 2004) suggest to limit the scope on intergenerational transfers from parents to their children.

Although fertility intentions were chosen to allow for a causal interpretation of the covariates' effects, the principal problem of causality remains. Women could select the transaction partners in their networks according to the resources they need to pursue their fertility intentions. For example, if 
they intend to have a child, they ask their parents and relatives for substantive support that enables them to put their reproductive plans into action. If they intend to postpone the birth of a child, their activities are less focused on this event and, for example, more related to problems in daily life. Therefore, direct reciprocal relationships with friends may be more often named because these are major sources for borrowed money. This problem is caused by the fact that the information about the respondents' social capital rests to a large extent on concrete transactions within a particular period. Thus, these activities may reflect intentions that already exist. Panel information would reduce this problem and so would a measurement of social capital that is not related to particular transactions and time periods. Future studies should have the latter aspect as a central focus since this would provide insight into the general stock of social capital and its implications on fertility intentions and reproductive behavior.

\section{Acknowledgments}

We want to thank Peter Preisendörfer and the two anonymous reviewers for their helpful comments as well as Susann Backer for editing the article's English.

\section{Literature}

Ajzen, I. 1991. "The theory of planned behavior." Organizational Behavior and Human Decision Processes 50, pp. 179-211.

Alt, C. 1994. „Reziprozität von Eltern-Kind-Beziehungen in Mehrgenerationennetzwerken.“ In: W. Bien (ed.) Eigeninteresse oder Solidarität? Beziehungen in modernen Mehrgenerationenfamilien. Opladen, Leske + Budrich, pp. 197-222.

Astone, N.M., C.A. Nathanson, R. Schoen, and Y.J. Kim. 1999. "Family demography, social theory, and investment in social capital." Population and Development Review 25, pp. 1-31.

Bearman, P. 1997. "Generalized exchange.” American Journal of Sociology 102, pp. 1383-1415.

Bernard, H.R., E.C. Johnsen, P.D. Killworth, C. McCarthy, G.A. Shelley, and S. Robinson. 1990. "Comparing four different methods for measuring personal social networks." Social Networks 12 , pp. 179-215.

Bongaarts, J. 2002. "The end of fertility transition in the developed World." Population and Development Review 28, pp. 419-444.

Bongaarts, J. and G. Feeney. 1998. "On the quantum and tempo of fertility." Population and Development Review 24, pp. 271-292.

Bongaarts, J. and S.C. Watkins. 1996. "Social interactions and contemporary fertility transitions." Population and Development Review 22, pp. 639-682.

Bourdieu, P. 1983. „Ökonomisches Kapital, kulturelles Kapital, soziales Kapital.“ In: R. Kreckel (ed.), Soziale Ungleichheiten. Soziale Welt Sonderband 2. Göttingen, Schwarz, pp. 183-198.

Brähler, E., Y. Ströbel-Richter, and J. Schumacher. 2001. „Für und Wider eines eigenen Kindes: Der Leipziger Fragebogen zu Kinderwunschmotiven (LKM).“ Diagnostica 47, pp. 96-106.

Bühler, C. 2005. "How much do inequalities of income matter for fertility intentions in transitional societies? Some empirical descriptions from Bulgaria." Paper presented at Annual Meeting of the Population Association of America, Philadelphia, April 2005.

Bühler, C. 2004. "Additional work, family agriculture, and the birth of a first or a second child in Russia at the beginning of the 1990s." Population Research and Policy Review 23, pp. 259-289. 
Bühler, C. and E. Fratczak. 2004. "Social capital and fertility intentions: The case of Poland." MPIDR Working Paper WP-2004-012, Rostock: Max-Planck-Institute for Demographic Research.

Bühler, C. and H.-P. Kohler. 2004. „Der Einfluss starker Beziehungen auf die Nutzung moderner Kontrazeptiva in Kenia." Zeitschrift für Soziologie 33, pp. 5-25.

Buka, S.L., R.T. Brennan, J.W. Rich-Edwards, S.W. Raudenbush, and F. Earls. 2003. "Neighborhood support and the birth weight of urban infants." American Journal of Epidemology 157, pp. 1-8.

Bulatao, R.A. 1981. "Values and disvalues of children in successive childbearing decisions." Demography 18, pp. 1-25.

Burt, R.S. 1982. Toward a structural theory of action. Network models of social structure, perception, and action. New York: Academic Press.

Carley, K. M. 2001. "Learning and using new ideas: A sociocognitive perspective.” In: J.B. Casterline (ed.), Diffusion processes and fertility transition. Selected perspectives. Washington, D.C., National Academy Press, pp. 179-207

Casterline, J.B. 2001. "Diffusion processes and fertility transition: Introduction." In: J.B. Casterline (ed.), Diffusion processes and fertility transition. Selected perspectives. Washington, D.C., National Academy Press, pp. 1-38.

Coleman, J.S. 1990. Foundations of social theory. Harvard: Belknap.

Dennis, I. and A.C. Guio. 2004. „Monetäre Armut in den neuen Mitgliedstaaten und den Bewerberländern.“ Statistik kurz gefasst: Bevölkerung und soziale Bedingungen 12/2000, Luxemburg: Eurostat.

Dershem, L. and D. Gzirishvili. 1998. Informal social support networks and household vulnerability: Empirical findings from Georgia." World Development 26, pp. 1827-1838.

Diewald, M. 1991. Soziale Beziehungen: Verlust oder Liberalisierung? Soziale Unterstützung in informellen Netzwerken. Berlin: Edition Sigma.

Ekeh, P. 1974. Social exchange theory: The two traditions. Cambridge: Harvard University Press.

Emerson, R.M. 1976. "Social exchange theory." Annual Review of Sociology 2, pp. 335-362.

Entwisle, B., R.R. Rindfuss, D.K. Guilkey, A. Chamratrithirong, S.R. Curran, and Y. Sawangdee. 1996. "Community and contraceptive choice in rural Thailand: A case study of Nan Rong." Demography 33, pp. 1-11.

Flap, H. 2002. "No man is an island." In: O. Favereau and E. Lazega (eds.), Conventions and structures in economic organization: Markets, networks, and hierarchies. London, Edward Elgar, pp. 29-59

Floge, L. 1985. "The dynamics of child-care use and some implications for women's employment." Journal of Marriage and the Family 47, pp. 143-154.

Goodwin, R., G. Nizharadze, L.A. Nguyen Luu, E. Kosa, and T. Emelyanova. 2001. "Social support in a changing Europe: An analysis of three post-communist nations." European Journal of Social Psychology 31, pp. 379-393.

Gouldner, A.W. 1960. "The norm of reciprocity: A preliminary statement." American Sociological Review 25, pp. 161-178.

Hank, K., M. Kreyenfeld, and C.K. Spieß. 2003. „Kinderbetreuung und Fertilität in Deutschland.“ MPIDR Working Paper WP 2003-002, Rostock: Max Planck Institute for Demographic Research.

Hao, L. 1995. "How does a single mother choose kin and welfare support?" Social Science Research 24, pp. 1-27.

Haug, S. 2000. Soziales Kapital und Kettenmigration. Italienische Migranten in Deutschland. Opladen: Leske + Budrich.

Hawe, P. and A. Shiell. 2000. "Social capital and health promotion." Social Science \& Medicine 51, pp. 871-885.

Hogan, D.P., L.-X. Hao, and W.L. Parish. 1990. "Race, kin networks, and assistance to motherheaded families." Social Forces 68, pp. 797-812. 
Homans, G.C. 1972(1961). Elementarformen des sozialen Verhaltens. Wiesbaden: Westdeutscher Verlag.

Kawachi, I., B.P. Kennedy, K. Lochner, and D. Prothrow-Stith. 1997. "Social capital, income inequality, and mortality." American Journal of Public Health 87, pp. 1491-1498.

Kohler, H.-P. 2001. Fertility and social interactions: An economic perspective. Oxford: Oxford University Press.

Kohler, H.-P., J.R. Behrman, and S.C. Watkins. 2001. "The structure of social networks and fertility decisions: Evidence from South Nyanza district, Kenya." Demography 38, pp. 43-58.

Kohler, H.-P., F.C. Billari, and J.A. Ortega. 2002. "The emergence of lowest-low fertility in Europe during the 1990s." Population and Development Review 28, pp. 641-680.

Lin, N. 2001. Social capital. A theory of social structure and action. Cambridge: Cambridge University Press.

Lokshin, M.M. and R. Yemtsov. 2001. "Household strategies for coping with poverty and social exclusion in post-crisis Russia." Policy Research Working Papers 2556, Washington, DC: The World Bank.

Lokshin, M.M., K. Mullan Harris, and B.M. Popkin. 2000. Single mothers in Russia: Household strategies for coping with poverty." World Development 28, pp. 2183-2198.

Lonkila, M. 1999. Social networks in post-soviet Russia. Continuity and change in the everyday life of St. Petersburg teachers. Helsinki: Kikimora Publications.

Lonkila, M. 1997. „Informal exchange relations in post-soviet Russia: A comparative perspective,” Sociological Research Online 2, http://www.socresonline.or.uk/ socresonline/2/2/9.html.

Mahrbach, J.H. 1994. „Tauschbeziehungen zwischen Generationen: Kommunikation, Dienstleistungen und finanzielle Unterstützung in Dreigenerationenfamilien.“ In: W. Bien (ed.) Eigeninteresse oder Solidarität? Beziehungen in modernen Mehrgenerationenfamilien. Opladen, Leske + Budrich, pp. 163-196.

Martín, A.R. and M.A. Ruiz Jiménez. 2001. "Epidemiological assessment of the influence of sociofamily factors in adolescent pregnancy." European Journal of Epidemiology 17, pp. 653-659.

Miller, W.B. 1994. "Childbearing motivations, desires, and intentions: A theoretical framework." Genetic, Social, and General Psychology Monographs 120, pp. 223-258.

Miller, W.B. and D.J. Pasta. 1995. "How does childbearing affect fertility motivations and desires?" Social Biology 42, pp. 185-198.

Montgomery, M.R., G.-E. Kiros, D. Agyeman, J.B. Casterline, P. Aglobitse, and P.C. Hewett. 2001. "Social networks and contraceptive dynamics in Southern Ghana." Policy Research Division Working Paper 153, New York: Population Council.

Morgan, S.P. 2003. "Is low fertility a twenty-first-century demographic crisis?" Demography 40, pp. 589-603.

Morgan, S.P. and R. Berkowitz King. 2001. "Why have children in the $21^{\text {st }}$ century? Biological predisposition, social coercion, rational choice." European Journal of Population 17, pp. 3-20.

Nauck, B. 2001. „Der Wert von Kindern für ihre Eltern. ,Value of Children' als spezielle Handlungstheorie des generativen Verhaltens und von Generationenbeziehungen im interkulturellen Vergleich.“ Kölner Zeitschrift für Soziologie und Sozialpsychologie 53, pp. 407-435.

Nauck, B. 1989. „Individualistische Erklärungsansätze in der Familienforschung: die rational-choiceBasis von Familienökonomie, Ressourcen- und Austauschtheorien.“ In: R. Nave-Herz and M. Markefka (eds.) Handbuch der Familien- und Jugendforschung, Band 1: Familienforschung. Neuwied, Luchterhand.

Nye, F.I. 1979. "Choice, exchange, and the family." In: W.R. Barr, R. Hill, F.I. Nye, and I.L. Reiss (eds.) Contemporary theories about the family. General theories/theoretical considerations. New York, The Free Press, pp. 1-41. 
Palloni, A., D.S. Massey, M. Ceballos, K. Espinosa, and M. Spittel. 2001. "Social capital and international migration: A test using information of family networks." American Journal of Sociology 106, pp. 1262-1298.

Parish, W.L., L. Hao, and D.P. Hogan. 1991. "Family support networks, welfare, and work among young mothers." Journal of Marriage and the Family 53, pp. 203-215.

Perelli, B. 2004. "The influence of coping mechanisms and a positive outlook on childbearing during periods of economic uncertainty." Paper presented at Annual Meeting of the Population Association of America, Boston, MA, April 2004.

Petermann, S. 2002. Persönliche Netzwerke in Stadt und Land. Siedlungsstruktur und soziale Unterstützungsnetzwerke im Raum Halle/Saale. Wiesbaden: Westdeutscher Verlag.

Peterson, J.T. 1993. "Generalized extended family exchange: A case from the Philippines." Journal of Marriage and the Family 55, pp. 570-584.

Pevalin, D.J., T.J. Wade, A. Brannigan, and R. Sauve. 2001. "Beyond biology: The social context of prenatal behaviour and birth outcomes." Sozial- und Präventivmedizin 46, pp. 233-239.

Pfenning, U. 1995. Soziale Netzwerke in der Forschungspraxis. Darmstadt: DDD, Dr. und Verlag.

Philipov, D. 2003. "Fertility in times of discontinuous societal change." In: I.E. Kotowska and J. Jozwiak (eds.) Population of Central and Eastern Europe: Challenges and opportunities. Warsaw, Statistical Publishing Establishment, pp. 665-690.

Philipov, D. and J. Dorbritz. 2003. Demographic consequences of economic transition in countries of Central and Eastern Europe. Strasbourg: Council of Europe Publishing.

Philipov, D. and V. Shkolnikov. 2001. "Fertility intentions and coping strategies: Results from the Russian Longitudinal Monitoring Survey." Paper presented at the Annual Meeting of the Popиlation Association of America, Washington D.C, March, 2001.

Philipov, D., Z. Spéder, and F.C. Billary. 2005. Tempo and quantum fertility intentions: A study of Bulgaria and Hungary. Unpublished manuscript.

Portes, A. 1998. "Social capital: Its origins and applications in modern sociology." Annual Review of Sociology 24, pp. 1-24.

Quarantelli, E.L. 1960. "A Note on the protective function of the family in disasters." Marriage and Family Living 22, pp. 263-264

Quesnel-Vallée, A. and S.P. Morgan. 2003. "Missing the target? Correspondence of fertility intentions and behavior in the U.S." Population Research and Policy Review 22, pp. 497-525.

Rogers, E.M. and L.D. Kincaid. 1981. Communication networks. Toward a new paradigm for research. New York: The Free Press.

Schoen, R., Y.J. Kim, C.A. Nathanson, J. Fieldsu, and N.M. Aston. 1997. "Why do Americans want children?" Population and Development Review 23, pp. 333-358.

Schulz, R. 1996. „Der Familienstand als Determinante der Struktur des familialen Hilfs- und Unterstützungsnetzwerks.“ Zeitschrift für Bevölkerungswissenschaft 21, pp. 3-27.

Sik, E. 1995. "Network capital in capitalist, communist, and post-communist societies." Working Paper 212, Notre Dame: University of Notre Dame, The Helen Kellogg Institute for International Studies.

Stegbauer, C. 2002. Reziprozität. Einführung in soziale Formen der Gegenseitigkeit. Wiesbaden: Westdeutscher Verlag.

Szreter, S. and M. Woolcock. 2004. "Health by association? Social capital, social theory, and the political economy of public health." International Journal of Epidemiology 33, pp. 650-667.

Takahishi, N. 2000. "The emergence of generalized exchange." American Journal of Sociology 105, pp. 1105-1134.

UNECE. 2002. Economic survey of Europe, 2002, No. 2. Geneva: United Nations Publication.

Valente, T.W., S.C. Watkins, M.N. Jato, A. van der Straten, and L.-P.M. Tsitsol. 1997. "Social network associations with contraceptive use among Cameroonian women in voluntary associations." Social Science \& Medicine 45, pp. 677-687. 
van de Kaa, D. 1988. "The Second Demographic Transition revisited: Theories and expectations." Paper presented at the Symposium on Population Change and European Society, Florence, December 1988.

Wellman, B. 1992. "Which types of ties and networks provide what kinds of social support?" In: E.J. Lawler, B. Mankowsky, C. Ridgeway, and H.A. Walker (eds.) Advances in group processes 9, Greenwich, JAI Press, pp. 207-235.

Wellman, B. and S. Wortley. 1990. "Different strokes from different folks: Community ties and social support." American Journal of Sociology 96, pp. 558-588.

Yamagishi, T. and K.S. Cook. 1993. "Generalized exchange and social dilemmas." Social Psychology Quarterly 56, pp. 235-248.

Yamaguchi, K. and L.R. Ferguson. 1995. "The stopping and spacing of childbirths and their birthhistory predictors: Rational choice theory and event-history analysis." American Sociological Review 60, pp. 272-298.

Ziegler, R. 1990. "The Kula: Social order, barter and ceremonial exchange.” In: M. Hechter, K.-D. Opp, and R. Wippler (eds.) Social institutions. Their emergence, maintenance, and effects. Berlin and New York, de Gruyter, pp. 141-168. 
Table 1:

\begin{tabular}{|c|c|c|c|c|c|c|}
\hline \multirow[b]{3}{*}{ Variable } & \multirow[b]{3}{*}{ Description } & \multicolumn{5}{|c|}{ Descriptive statistics } \\
\hline & & \multicolumn{2}{|c|}{ First child } & \multicolumn{2}{|c|}{ Second child } & \multirow{2}{*}{$\begin{array}{c}\text { Third } \\
\text { child } \\
\text { Quan- } \\
\text { tum }\end{array}$} \\
\hline & & $\begin{array}{l}\text { Quan- } \\
\text { tum }\end{array}$ & $\begin{array}{l}\text { Tim- } \\
\text { ing }\end{array}$ & $\begin{array}{l}\text { Quan- } \\
\text { tum }\end{array}$ & $\begin{array}{l}\text { Tim- } \\
\text { ing }\end{array}$ & \\
\hline \multicolumn{7}{|c|}{ Dependent variable } \\
\hline Quantum & $\begin{array}{l}\text { Intention ever to have a first or another child: } \\
1=\text { 'definitely no', } 2=\text { 'probably no', } 3=\text { 'proba- } \\
\text { bly yes', } 4=\text { 'definitely yes' }\end{array}$ & $\begin{array}{l}3.78 \\
(0.675)\end{array}$ & -- & $\begin{array}{l}2.89 \\
(1.173)\end{array}$ & -- & $\begin{array}{l}1.32 \\
(0.680)\end{array}$ \\
\hline Timing & $\begin{array}{l}\text { Intention to have a first or another child within } \\
\text { the next two years: } 1=\text { 'definitely no', } 2= \\
\text { 'probably no', } 3=\text { 'probably yes', } 4=\text { 'definitely } \\
\text { yes" }\end{array}$ & -- & $\begin{array}{l}3.03 \\
(1.017)\end{array}$ & -- & $\begin{array}{l}2.56 \\
(0.961)\end{array}$ & -- \\
\hline \multicolumn{7}{|c|}{ Characteristics of respondent } \\
\hline Age: & & & & & & \\
\hline 18 to 20 & $1=$ 'yes', $0=$ 'no' & $\begin{array}{l}0.08 \\
(0.271)\end{array}$ & $\begin{array}{l}0.08 \\
(0.267)\end{array}$ & $\begin{array}{l}0.04 \\
(0.196)\end{array}$ & $\begin{array}{l}0.04 \\
(0.200)\end{array}$ & $\begin{array}{l}0.01 \\
(0.102)\end{array}$ \\
\hline 21 to 25 & $1=$ 'yes', $0=$ 'no' & $\begin{array}{l}0.43 \\
(0.496)\end{array}$ & $\begin{array}{l}0.42 \\
(0.495)\end{array}$ & $\begin{array}{l}0.28 \\
(0.451)\end{array}$ & $\begin{array}{c}0.34 \\
(0.473)\end{array}$ & $\begin{array}{c}0.09 \\
(0.289)\end{array}$ \\
\hline 26 to 30 & $1=$ 'yes', $0=$ 'no' & $\begin{array}{c}0.36 \\
(0.482)\end{array}$ & $\begin{array}{l}0.38 \\
(0.487)\end{array}$ & $\begin{array}{l}0.40 \\
(0.491)\end{array}$ & $\begin{array}{c}0.43 \\
(0.495)\end{array}$ & $\begin{array}{l}0.36 \\
(0.482)\end{array}$ \\
\hline 31 to 34 & Reference category & $\begin{array}{l}0.13 \\
(0.338)\end{array}$ & $\begin{array}{l}0.12 \\
(0.330)\end{array}$ & $\begin{array}{c}0.27 \\
(0.446)\end{array}$ & $\begin{array}{c}0.20 \\
(0.398)\end{array}$ & $\begin{array}{c}0.53 \\
(0.500)\end{array}$ \\
\hline $\begin{array}{l}\text { Tertiary educa- } \\
\text { tion }\end{array}$ & $\begin{array}{l}\text { Degree or currently in tertiary education } \\
1=\text { 'yes', } 0=\text { 'no' }\end{array}$ & $\begin{array}{l}0.42 \\
(0.495)\end{array}$ & $\begin{array}{l}0.42 \\
(0.495)\end{array}$ & $\begin{array}{c}0.33 \\
(0.469)\end{array}$ & $\begin{array}{c}0.33 \\
(0.472)\end{array}$ & $\begin{array}{l}0.23 \\
(0.416)\end{array}$ \\
\hline $\begin{array}{l}\text { Intended educa- } \\
\text { tion }\end{array}$ & $\begin{array}{l}\text { Intention to start an education within the next two } \\
\text { years. } 1=\text { 'yes', } 0=\text { 'no' }\end{array}$ & $\begin{array}{l}0.15 \\
(0.356)\end{array}$ & $\begin{array}{l}0.14 \\
(0.349)\end{array}$ & -- & -- & -- \\
\hline \multicolumn{7}{|c|}{ Employment situation: } \\
\hline $\begin{array}{l}\text { Gainfully } \\
\text { employed }\end{array}$ & $\begin{array}{l}\text { Employed or self-employed work during the last } \\
\text { three months } 1=\text { 'yes', } 0=\text { 'no' }\end{array}$ & $\begin{array}{l}0.69 \\
(0.462)\end{array}$ & $\begin{array}{l}0.71 \\
(0.457)\end{array}$ & $\begin{array}{l}0.54 \\
(0.499)\end{array}$ & $\begin{array}{l}0.51 \\
(0.500)\end{array}$ & $\begin{array}{l}0.59 \\
(0.492)\end{array}$ \\
\hline In education & $1=$ 'yes', $0=$ 'no' & $\begin{array}{l}0.09 \\
(0.288)\end{array}$ & $\begin{array}{l}0.09 \\
(0.284)\end{array}$ & $\begin{array}{l}0.03 \\
(0.170)\end{array}$ & $\begin{array}{l}0.03 \\
(0.183)\end{array}$ & $\begin{array}{c}0.004 \\
(0.065)\end{array}$ \\
\hline Not working & $\begin{array}{l}\text { Not working due to parental leave, housewife, } \\
\text { health problems, other reasons. } 1=\text { 'yes', } 0=\text { 'no' }\end{array}$ & $\begin{array}{l}0.01 \\
(0.106)\end{array}$ & $\begin{array}{l}0.01 \\
(0.108)\end{array}$ & $\begin{array}{l}0.29 \\
(0.456)\end{array}$ & $\begin{array}{l}0.34 \\
(0.475)\end{array}$ & $\begin{array}{l}0.28 \\
(0.448)\end{array}$ \\
\hline Unemployed & $\begin{array}{l}\text { Registered and unregistered unemployment } \\
\text { (reference category) }\end{array}$ & $\begin{array}{l}0.20 \\
(0.405)\end{array}$ & $\begin{array}{l}0.19 \\
(0.397)\end{array}$ & $\begin{array}{l}0.14 \\
(0.346)\end{array}$ & $\begin{array}{c}0.11 \\
(0.318)\end{array}$ & $\begin{array}{l}0.13 \\
(0.332)\end{array}$ \\
\hline Religiosity & $\begin{array}{l}\text { Respondent perceives herself as a religious person } \\
1=\text { 'yes', } 0=\text { 'no' }\end{array}$ & $\begin{array}{l}0.59 \\
(0.493)\end{array}$ & $\begin{array}{l}0.57 \\
(0.496)\end{array}$ & $\begin{array}{c}0.61 \\
(0.488)\end{array}$ & $\begin{array}{c}0.63 \\
(0.483)\end{array}$ & $\begin{array}{c}0.61 \\
(0.489)\end{array}$ \\
\hline Siblings & Number of siblings & $\begin{array}{l}1.01 \\
(0.689)\end{array}$ & -- & $\begin{array}{l}1.10 \\
(0.823)\end{array}$ & -- & $\begin{array}{l}1.25 \\
(1.002)\end{array}$ \\
\hline \multicolumn{7}{|c|}{$\begin{array}{l}\text { Characteristics of husband or partner } \\
\text { Age: }\end{array}$} \\
\hline 18 to 25 & $1=$ 'yes', $0=$ 'no' & $\begin{array}{l}0.25 \\
(0.434)\end{array}$ & $\begin{array}{l}0.24 \\
(0.425)\end{array}$ & $\begin{array}{l}0.11 \\
(0.308)\end{array}$ & $\begin{array}{l}0.12 \\
(0.325)\end{array}$ & $\begin{array}{l}0.03 \\
(0.157)\end{array}$ \\
\hline 26 to 30 & $1=$ 'yes', $0=$ 'no' & $\begin{array}{l}0.41 \\
(0.494)\end{array}$ & $\begin{array}{l}0.44 \\
(0.498)\end{array}$ & $\begin{array}{l}0.35 \\
(0.478)\end{array}$ & $\begin{array}{l}0.42 \\
(0.495)\end{array}$ & $\begin{array}{c}0.19 \\
(0.393)\end{array}$ \\
\hline 31 to 35 & 1 = 'yes', 0 = 'no' & $\begin{array}{l}0.25 \\
(0.434)\end{array}$ & $\begin{array}{l}0.24 \\
(0.429)\end{array}$ & $\begin{array}{l}0.35 \\
(0.478)\end{array}$ & $\begin{array}{l}0.33 \\
(0.471)\end{array}$ & $\begin{array}{c}0.45 \\
(0.498)\end{array}$ \\
\hline 36 to 66 & Reference category & $\begin{array}{l}0.05 \\
(0.221)\end{array}$ & $\begin{array}{l}0.05 \\
(0.225)\end{array}$ & $\begin{array}{l}0.14 \\
(0.352)\end{array}$ & $\begin{array}{c}0.10 \\
(0.303)\end{array}$ & $\begin{array}{c}0.26 \\
(0.439)\end{array}$ \\
\hline $\begin{array}{l}\text { Tertiary educa- } \\
\text { tion }\end{array}$ & $\begin{array}{l}\text { Degree or currently in tertiary education. } \\
1=\text { 'yes', } 0=\text { 'no' }\end{array}$ & $\begin{array}{l}0.26 \\
(0.437)\end{array}$ & $\begin{array}{l}0.26 \\
(0.442)\end{array}$ & $\begin{array}{c}0.18 \\
(0.382)\end{array}$ & $\begin{array}{l}0.20 \\
(0.400)\end{array}$ & $\begin{array}{c}0.15 \\
(0.354)\end{array}$ \\
\hline Employment sitı & ation: & & & & & \\
\hline $\begin{array}{l}\text { Gainfully } \\
\text { employed }\end{array}$ & $\begin{array}{l}\text { Employed or self-employed work during the last } \\
\text { three months. } 1=\text { 'yes', } 0=\text { 'no' }\end{array}$ & $\begin{array}{c}0.82 \\
(0.382) \\
\end{array}$ & $\begin{array}{l}0.85 \\
(0.361) \\
\end{array}$ & $\begin{array}{c}0.86 \\
(0.342) \\
\end{array}$ & $\begin{array}{l}0.88 \\
(0.325)\end{array}$ & $\begin{array}{l}0.85 \\
(0.360) \\
\end{array}$ \\
\hline
\end{tabular}

Continued on the next page 
Table 1 (continued)

\begin{tabular}{|c|c|c|c|c|c|c|}
\hline \multicolumn{7}{|c|}{ Characteristics of household } \\
\hline $\begin{array}{l}\text { Equivalence } \\
\text { income } / 10\end{array}$ & $\begin{array}{l}\text { Household income per weighted household } \\
\text { member in units of } 10 \text { Leva. }\end{array}$ & $\begin{array}{l}22.86 \\
(16.121)\end{array}$ & $\begin{array}{l}23.28 \\
(16.254)\end{array}$ & $\begin{array}{l}17.95 \\
(11.278)\end{array}$ & $\begin{array}{l}18.67 \\
(12.041)\end{array}$ & $\begin{array}{l}15.14 \\
(10.021)\end{array}$ \\
\hline Rural area & $\begin{array}{l}\text { Respondents' place of residence is a small town } \\
\text { or village. } 1=\text { 'yes', } 0=\text { 'no' }\end{array}$ & $\begin{array}{c}0.13 \\
(0.332) \\
\end{array}$ & $\begin{array}{c}0.13 \\
(0.337) \\
\end{array}$ & $\begin{array}{c}0.15 \\
(0.362) \\
\end{array}$ & $\begin{array}{c}0.15 \\
(0.354) \\
\end{array}$ & $\begin{array}{c}0.23 \\
(0.420) \\
\end{array}$ \\
\hline \multicolumn{7}{|l|}{ Network size } \\
\hline \multicolumn{7}{|c|}{ Resources received: } \\
\hline Small help & $\begin{array}{l}\text { Number of network partners from whom the } \\
\text { respondent receives 'small help' }\end{array}$ & $\begin{array}{l}4.04 \\
(3.117)\end{array}$ & $\begin{array}{c}4.31 \\
(4.133)\end{array}$ & $\begin{array}{l}3.37 \\
(2.193)\end{array}$ & $\begin{array}{l}3.52 \\
(2.250)\end{array}$ & $\begin{array}{l}3.47 \\
(2.551)\end{array}$ \\
\hline $\begin{array}{l}\text { Important } \\
\text { support }\end{array}$ & $\begin{array}{l}\text { Number of network partners from whom the } \\
\text { respondent receives 'important and substantive } \\
\text { support' }\end{array}$ & $\begin{array}{l}2.51 \\
(1.538)\end{array}$ & $\begin{array}{l}2.51 \\
(1.577)\end{array}$ & $\begin{array}{l}2.45 \\
(1.620)\end{array}$ & $\begin{array}{l}2.54 \\
(1.574)\end{array}$ & $\begin{array}{l}2.46 \\
(1.782)\end{array}$ \\
\hline $\begin{array}{l}\text { Borrowing } \\
\text { money }\end{array}$ & $\begin{array}{l}\text { Number of network partners from whom the } \\
\text { respondent borrows money }\end{array}$ & $\begin{array}{l}2.38 \\
(2.030)\end{array}$ & $\begin{array}{l}2.40 \\
(2.045)\end{array}$ & $\begin{array}{l}2.12 \\
(1.728)\end{array}$ & $\begin{array}{l}2.16 \\
(1.638)\end{array}$ & $\begin{array}{l}2.11 \\
(1.574)\end{array}$ \\
\hline \multicolumn{7}{|c|}{ Resources given: } \\
\hline $\begin{array}{l}\text { Important } \\
\text { support }\end{array}$ & $\begin{array}{l}\text { Number of network partner that ask the respon- } \\
\text { dent for 'important and substantive support' when } \\
\text { needed }\end{array}$ & $\begin{array}{l}2.78 \\
(2.679)\end{array}$ & $\begin{array}{l}2.69 \\
(2.366)\end{array}$ & $\begin{array}{l}2.56 \\
(2.035)\end{array}$ & $\begin{array}{l}2.63 \\
(2.040)\end{array}$ & $\begin{array}{l}2.77 \\
(2.899)\end{array}$ \\
\hline $\mathbf{N}$ & & 176 & 170 & 879 & 578 & 478 \\
\hline \multicolumn{7}{|c|}{ Number of indirect and direct reciprocal relationships } \\
\hline \multirow{2}{*}{$\begin{array}{l}\text { Number of indi- } \\
\text { rect reciprocal } \\
\text { relationships } \\
\text { Number of } \\
\text { direct parents: } \\
\text { one }\end{array}$} & $\begin{array}{l}\text { Number of direct parents, parents-in-law, siblings, } \\
\text { grand parents, and other relatives. }\end{array}$ & $\begin{array}{l}2.00 \\
(1.282)\end{array}$ & $\begin{array}{l}1.96 \\
(1.322)\end{array}$ & $\begin{array}{l}1.88 \\
(1.354)\end{array}$ & $\begin{array}{c}1.93 \\
(1.322)\end{array}$ & $\begin{array}{c}1.91 \\
(1.448)\end{array}$ \\
\hline & One direct parent named. $1=$ 'yes', $0=$ 'no' & $\begin{array}{c}0.34 \\
(0.474)\end{array}$ & $\begin{array}{l}0.35 \\
(0.477)\end{array}$ & $\begin{array}{c}0.39 \\
(0.487)\end{array}$ & $\begin{array}{c}0.41 \\
(0.493)\end{array}$ & $\begin{array}{c}0.34 \\
(0.475)\end{array}$ \\
\hline two & Both direct parents named. $1=$ 'yes', $0=$ 'no' & $\begin{array}{l}0.39 \\
(0.490)\end{array}$ & $\begin{array}{l}0.37 \\
(0.483)\end{array}$ & $\begin{array}{l}0.28 \\
(0.451)\end{array}$ & $\begin{array}{l}0.28 \\
(0.451)\end{array}$ & $\begin{array}{c}0.29 \\
(0.453)\end{array}$ \\
\hline $\begin{array}{l}\text { Number of } \\
\text { other relatives }\end{array}$ & $\begin{array}{l}\text { Number of parents-in-law, siblings, grand parents, } \\
\text { and other relatives. }\end{array}$ & $\begin{array}{c}0.88 \\
(1.030)\end{array}$ & $\begin{array}{l}0.88 \\
(1.026)\end{array}$ & $\begin{array}{l}0.93 \\
(1.043)\end{array}$ & $\begin{array}{l}0.95 \\
(1.020)\end{array}$ & $\begin{array}{l}0.98 \\
(1.110)\end{array}$ \\
\hline $\begin{array}{l}\text { Number of direct } \\
\text { reciprocal rela- } \\
\text { tionships }\end{array}$ & $\begin{array}{l}\text { Number of friends, colleagues, neighbors, and } \\
\text { acquaintances }\end{array}$ & $\begin{array}{l}0.92 \\
(1.251)\end{array}$ & $\begin{array}{l}0.93 \\
(0.241)\end{array}$ & $\begin{array}{l}0.86 \\
(0.171)\end{array}$ & $\begin{array}{l}0.85 \\
(0.152)\end{array}$ & $\begin{array}{l}0.88 \\
(0.239)\end{array}$ \\
\hline $\mathbf{N}$ & & 158 & 153 & 782 & 523 & 431 \\
\hline
\end{tabular}


Table 2:

Intention ever to have a first or another child by the number of children belonging to the respondent (natural children, step, and fostered children)

\begin{tabular}{|c|c|c|c|c|c|}
\hline \multirow[b]{2}{*}{ Intention ever to have a first or another child } & \multicolumn{4}{|c|}{ Number of children } & \multirow[t]{2}{*}{ Total } \\
\hline & 0 & 1 & 2 & 3 or more & \\
\hline Definitely not & 3.0 & 20.1 & 75.2 & 85.0 & 36.1 \\
\hline Probably not & 2.6 & 17.3 & 17.9 & 7.5 & 15.5 \\
\hline Probably yes & 6.8 & 19.4 & 3.2 & 2.5 & 12.6 \\
\hline Definitely yes & 87.7 & 43.3 & 3.7 & 5.0 & 35.9 \\
\hline Total & 100.1 & 101.1 & 100.0 & 100.0 & 100.1 \\
\hline $\mathrm{N}$ & 235 & 1,072 & 588 & 40 & $1,935^{\mathrm{a}}$ \\
\hline
\end{tabular}

${ }^{\text {a }}$ Due to 81 cases with non response or missing information, the total number of respondents in this table is smaller than the overall population $(n=2,016)$ considered in the analyses. 
Table 3:

Intention to have a first or another child within the next two years by the number of children belonging to the respondent (natural children, step, and fostered children)

All respondents that definitely or probably intend to have a first or another child

Intention to have a first or another child Number of children Total within the next two years

\begin{tabular}{llcccc}
\hline Definitely not & 12.9 & 16.1 & 30.0 & -- & 16.0 \\
Probably not & 14.7 & 27.8 & 30.0 & 33.3 & 24.8 \\
Probably yes & 33.8 & 40.1 & 28.0 & 33.3 & 37.9 \\
Definitely yes & 38.7 & 16.1 & 12.0 & 33.3 & 21.2 \\
\hline Total & 100.1 & 100.1 & 100.0 & 99.9 & 99.9 \\
\hline $\mathrm{N}$ & 225 & 684 & 50 & 3 & 962 \\
\hline
\end{tabular}


Table 4:

Shares of empty networks and mean sizes of non-empty networks separated by the number of children belonging to the respondent (natural children, step, and fostered children)

\begin{tabular}{|c|c|c|c|c|c|c|c|c|c|c|}
\hline & \multicolumn{5}{|c|}{ Access to small help } & \multicolumn{5}{|c|}{ Access to important and substantive support } \\
\hline & \multirow[t]{2}{*}{ Total } & \multicolumn{4}{|c|}{ Number of children } & \multirow[t]{2}{*}{ Total } & \multicolumn{4}{|c|}{ Number of children } \\
\hline & & 0 & 1 & 2 & $\geq 3$ & & 0 & 1 & 2 & $\geq 3$ \\
\hline \multicolumn{11}{|l|}{ Empty networks $^{\mathrm{a}}$} \\
\hline Share (in percent) & 6.1 & 7.0 & 5.2 & 7.3 & 9.8 & 7.7 & 6.6 & 7.5 & 8.4 & 9.5 \\
\hline $\mathrm{N}$ & 2,002 & 259 & 1,096 & 606 & 41 & 2,001 & 259 & 1,093 & 607 & 42 \\
\hline \multicolumn{11}{|c|}{ Non-empty networks ${ }^{\mathrm{b}}$} \\
\hline $\begin{array}{l}\text { Mean } \\
\text { (Std.dev.) }\end{array}$ & $\begin{array}{c}3.7 \\
(2.53) \\
\end{array}$ & $\begin{array}{r}4.2 \\
(3.70) \\
\end{array}$ & $\begin{array}{c}3.6 \\
(2.24) \\
\end{array}$ & $\begin{array}{c}3.7 \\
(2.41) \\
\end{array}$ & $\begin{array}{c}3.4 \\
(2.11) \\
\end{array}$ & $\begin{array}{c}2.7 \\
(1.58) \\
\end{array}$ & $\begin{array}{c}2.6 \\
(1.47) \\
\end{array}$ & $\begin{array}{c}2.7 \\
(1.53) \\
\end{array}$ & $\begin{array}{c}2.7 \\
(1.71) \\
\end{array}$ & $\begin{array}{c}2.6 \\
(1.73) \\
\end{array}$ \\
\hline \multirow[t]{4}{*}{$\mathrm{N}$} & 1,879 & 241 & 1,039 & 562 & 37 & 1,847 & 242 & 1,011 & 556 & 38 \\
\hline & \multicolumn{5}{|c|}{ Access to borrowed money } & \multicolumn{5}{|c|}{ Important and substantive support given } \\
\hline & \multirow[t]{2}{*}{ Total } & \multicolumn{4}{|c|}{ Number of children } & \multirow[t]{2}{*}{ Total } & \multicolumn{4}{|c|}{ Number of children } \\
\hline & & 0 & 1 & 2 & $\geq 3$ & & 0 & 1 & 2 & $\geq 3$ \\
\hline \multicolumn{11}{|l|}{ Empty networks $^{\mathrm{a}}$} \\
\hline $\mathrm{N}$ & 2,006 & 259 & 1,097 & 608 & 42 & 1,965 & 252 & 1,071 & 601 & 41 \\
\hline \multicolumn{11}{|c|}{ Non-empty networks ${ }^{b}$} \\
\hline $\begin{array}{l}\text { Mean } \\
\text { (Std.dev.) }\end{array}$ & $\begin{array}{c}2.4 \\
(1.57)\end{array}$ & $\begin{array}{c}2.5 \\
(1.92)\end{array}$ & $\begin{array}{c}2.4 \\
(1.58)\end{array}$ & $\begin{array}{c}2.4 \\
(1.40)\end{array}$ & $\begin{array}{c}2.4 \\
(1.22)\end{array}$ & $\begin{array}{c}3.0 \\
(2.57)\end{array}$ & $\begin{array}{c}3.0 \\
(2.45)\end{array}$ & $\begin{array}{c}3.0 \\
(2.50)\end{array}$ & $\begin{array}{c}3.1 \\
(2.78)\end{array}$ & $\begin{array}{c}2.8 \\
(1.69)\end{array}$ \\
\hline $\mathrm{N}$ & 1,760 & 237 & 971 & 522 & 30 & 1,719 & 222 & 935 & 534 & 28 \\
\hline
\end{tabular}

${ }^{\mathrm{a}}$ The respondent did not report about an experienced transfer of this resource during the last two years and also does not know a network partner who would provide or would ask for this resource.

$\mathrm{b}$ The respondent experienced at least one transfer of this resource during the last two years or knows at least one network partner who would provide or would ask to be provided with this resource. 
Table 5:

Networks' compositions by relationships of direct and indirect reciprocity

\begin{tabular}{lcccc}
\hline & Total & $\begin{array}{c}\text { Important and } \\
\text { substantive sup- } \\
\text { port received }\end{array}$ & $\begin{array}{c}\text { Borrowing } \\
\text { money }\end{array}$ & $\begin{array}{c}\text { Important and } \\
\text { substantive } \\
\text { support given }\end{array}$ \\
\hline Indirect reciprocal relationships: & 0.30 & & & \\
Direct parents & $(0.288)$ & $(0.35$ & 0.29 & 0.25 \\
Extended family, kin & 0.25 & 0.23 & $(0.373)$ & $(0.321)$ \\
& $(0.278)$ & $(0.297)$ & 0.27 & 0.28 \\
Total & 0.55 & 0.58 & $(0.357)$ & $(0.343)$ \\
& $(0.336)$ & $(0.368)$ & 0.56 & 0.53 \\
Direct reciprocal relationships: & & & $(0.423)$ & $(0.401)$ \\
Friends, colleagues, & 0.23 & 0.14 & & \\
neighbors, acquaint. & $(0.306)$ & $(0.285)$ & $(0.417)$ & 0.25 \\
Partner, husband, & 0.21 & 0.27 & 0.05 & $0.363)$ \\
children & $(0.266)$ & $(0.326)$ & $(0.190)$ & $(0.322)$ \\
Total & 0.44 & 0.41 & 0.43 & 0.47 \\
& $(0.334)$ & $(0.366)$ & $(0.421)$ & $(0.400)$ \\
Other network partners & 0.004 & 0.01 & 0.01 & 0.003 \\
& $(0.050)$ & $(0.074)$ & $(0.100)$ & $(0.034)$ \\
\hline Total & 0.99 & 1.00 & 0.99 & 1.00 \\
\hline $\mathrm{N}$ & 1,719 & 1,494 & 946 & 1,067 \\
\hline
\end{tabular}

Note: The table reports the mean values and standard deviations (in parentheses) of the proportions of the particular relationships and groups. 
Table 6:

Determinants of fertility intentions: Access to social capital, respondents', their husbands'/partners' and their households' characteristics (ordinal logit regressions)

\begin{tabular}{|c|c|c|c|c|}
\hline \multirow[b]{2}{*}{ Variable } & \multirow{2}{*}{$\frac{\text { First child }}{\text { Timing }}$} & \multicolumn{2}{|c|}{ Second child } & \multirow{2}{*}{$\begin{array}{l}\text { Third child } \\
\text { Quantum }\end{array}$} \\
\hline & & Quantum & Timing & \\
\hline \multicolumn{5}{|c|}{ Characteristics of respondent } \\
\hline \multicolumn{5}{|l|}{ Age: } \\
\hline \multirow[t]{2}{*}{18 to 20} & -0.295 & 0.195 & $-0.888^{*}$ & \\
\hline & $(0.778)$ & $(0.394)$ & $(0.496)$ & 0.336 \\
\hline \multirow[t]{2}{*}{21 to 25} & -0.181 & $0.464 * *$ & $-0.751 * * *$ & $(0.468)$ \\
\hline & $(0.534)$ & $(0.221)$ & $(0.272)$ & \\
\hline \multirow[t]{2}{*}{26 to 30} & 0.760 & $0.423 * *$ & $-0.500 * *$ & 0.140 \\
\hline & $(0.480)$ & $(0.174)$ & $(0.229)$ & $(0.263)$ \\
\hline \multirow[t]{2}{*}{ Tertiary education } & -0.063 & $0.266 *$ & 0.135 & 0.426 \\
\hline & $(0.373)$ & $(0.158)$ & $(0.189)$ & $(0.282)$ \\
\hline \multirow[t]{2}{*}{ Intended education } & $-0.843^{*}$ & -- & -- & -- \\
\hline & $(0.437)$ & & & \\
\hline \multicolumn{5}{|l|}{ Employment situation: } \\
\hline \multirow[t]{2}{*}{ Gainfully employed } & 0.204 & 0.093 & -0.301 & $-0.678 *$ \\
\hline & $(0.426)$ & $(0.200)$ & $(0.259)$ & $(0.350)$ \\
\hline \multirow[t]{2}{*}{ In education } & -0.690 & -0.051 & $-0.867 *$ & -- \\
\hline & $(0.674)$ & $(0.413)$ & $(0.468)$ & \\
\hline \multirow[t]{2}{*}{ Not working } & -- & $0.378 *$ & $-0.690 * *$ & 0.020 \\
\hline & & $(0.218)$ & $(0.272)$ & $(0.377)$ \\
\hline \multirow[t]{2}{*}{ Religiosity } & 0.469 & $0.313 * *$ & -0.037 & $0.465 *$ \\
\hline & $(0.318)$ & $(0.130)$ & $(0.162)$ & $(0.239)$ \\
\hline \multirow[t]{2}{*}{ Siblings } & -- & 0.103 & -- & -0.118 \\
\hline & & $(0.085)$ & & $(0.150)$ \\
\hline \multicolumn{5}{|l|}{ Social capital } \\
\hline \multicolumn{5}{|l|}{ Resources received: } \\
\hline Small help & -0.057 & 0.027 & $-0.089 * *$ & $0.095 *$ \\
\hline & $(0.037)$ & $(0.035)$ & $(0.040)$ & $(0.049)$ \\
\hline Important support & $0.247 * *$ & $0.240 * *$ & $0.177 * * *$ & $0.522 * *$ \\
\hline & $(0.102)$ & $(0.101)$ & $(0.057)$ & $(0.242)$ \\
\hline Important support & -- & $-0.024 *$ & -- & $-0.081 * *$ \\
\hline (squared) & & $(0.013)$ & & $(0.038)$ \\
\hline Borrowing money & 0.030 & 0.021 & 0.072 & 0.040 \\
\hline & $(0.077)$ & $(0.041)$ & $(0.049)$ & $(0.077)$ \\
\hline Resources given: & & & & \\
\hline Important support & 0.055 & 0.023 & 0.035 & -0.034 \\
\hline & $(0.071)$ & $(0.036)$ & $(0.045)$ & $(0.055)$ \\
\hline Characteristics of husbar & artner & & & \\
\hline Age: & & & & \\
\hline 18 to 25 & 0.560 & $0.679 * *$ & -0.265 & -0.511 \\
\hline & $(0.697)$ & $(0.292)$ & $(0.360)$ & $(0.758)$ \\
\hline 26 to 30 & 0.352 & $0.921 * * *$ & -0.054 & -0.088 \\
\hline & $(0.623)$ & $(0.219)$ & $(0.282)$ & $(0.377)$ \\
\hline 31 to 35 & -0.474 & $0.460 * *$ & 0.121 & -0.203 \\
\hline & $(0.640)$ & $(0.188)$ & $(0.266)$ & $(0.273)$ \\
\hline Tertiary education & 0.387 & $0.383 * *$ & -0.135 & 0.279 \\
\hline & $(0.402)$ & $(0.190)$ & $(0.221)$ & $(0.332)$ \\
\hline Employment situation: & & & & \\
\hline Gainfully employed & -0.127 & 0.055 & -0.195 & -0.057 \\
\hline & $(0.459)$ & $(0.196)$ & $(0.250)$ & $(0.342)$ \\
\hline Characteristics of housel & & & & \\
\hline Equivalence income/10 & $-0.040 * * *$ & 0.008 & 0.004 & $0.024 * *$ \\
\hline & $(0.011)$ & $(0.007)$ & $(0.007)$ & $(0.012)$ \\
\hline Rural area & 0.110 & 0.172 & $0.437 *$ & -0.041 \\
\hline & $(0.484)$ & $(0.189)$ & $(0.228)$ & $(0.291)$ \\
\hline
\end{tabular}

Continued on the next page 
Tabelle 6 (continued)

\begin{tabular}{ccccc}
\hline Cut points & & & & \\
1 & -2.052 & 0.754 & -2.279 & 2.348 \\
& $(0.754)$ & $(0.346)$ & $(0.457)$ & $(0.607)$ \\
2 & -0.926 & 1.890 & -0.867 & 4.045 \\
& $(0.729)$ & $(0.350)$ & $(0.448)$ & $(0.636)$ \\
3 & 0.682 & 2.563 & 1.143 & 4.726 \\
& $(0.727)$ & $(0.356)$ & $(0.448)$ & $(0.663)$ \\
\hline LL & -198.039 & -1092.399 & -733.994 & -320.532 \\
$\chi 2$ & 33.72 & 94.31 & 55.83 & 41.09 \\
df & 19 & 21 & 20 & 19 \\
\hline $\mathrm{N}$ & 170 & 879 & 578 & 478 \\
\hline
\end{tabular}

Unstandardized coefficients (standard errors)

Levels of Significance: $* \leq 0.1 ; * * \leq 0.05 ; * * * \leq 0.01$. 
Table 7:

Determinants of fertility intentions: Indirect and direct reciprocal relationships (ordinal logistic regression)

\begin{tabular}{|c|c|c|c|c|c|c|c|c|}
\hline & \multirow{2}{*}{\multicolumn{2}{|c|}{$\begin{array}{c}\text { First child } \\
\text { Timing }\end{array}$}} & \multicolumn{4}{|c|}{ Second child } & \multirow{2}{*}{\multicolumn{2}{|c|}{$\begin{array}{l}\text { Third child } \\
\text { Quantum }\end{array}$}} \\
\hline & & & \multicolumn{2}{|c|}{ Quantum } & \multicolumn{2}{|c|}{ Timing } & & \\
\hline & Model 1 & Model 2 & Model 1 & Model 2 & Model 1 & Model 2 & Model 1 & Model 2 \\
\hline $\begin{array}{l}\text { Number of indirect recipro- } \\
\text { cal relationships }\end{array}$ & $\begin{array}{l}0.285^{* *} \\
(0.135)\end{array}$ & -- & $\begin{array}{l}0.112 * * \\
(0.052)\end{array}$ & -- & $\begin{array}{l}0.120^{*} \\
(0.063)\end{array}$ & -- & $\begin{array}{c}0.049 \\
(0.083)\end{array}$ & -- \\
\hline \multicolumn{9}{|l|}{ Number of direct parents: } \\
\hline One & -- & $\begin{array}{c}0.140 \\
(0.396)\end{array}$ & -- & $\begin{array}{c}0.271 * \\
(0.162)\end{array}$ & -- & $\begin{array}{c}0.172 \\
(0.194)\end{array}$ & -- & $\begin{array}{l}-0.077 \\
(0.292)\end{array}$ \\
\hline Two & -- & $\begin{array}{l}1.023 * * \\
(0.426)\end{array}$ & -- & $\begin{array}{c}0.285 \\
(0.179)\end{array}$ & -- & $\begin{array}{l}0.495 * * \\
(0.215)\end{array}$ & -- & $\begin{array}{l}-0.227 \\
(0.314)\end{array}$ \\
\hline Number of other relatives & -- & $\begin{array}{c}0.184 \\
(0.176)\end{array}$ & -- & $\begin{array}{c}0.089 \\
(0.069)\end{array}$ & -- & $\begin{array}{c}0.045 \\
(0.082)\end{array}$ & -- & $\begin{array}{c}0.130 \\
(0.105)\end{array}$ \\
\hline $\begin{array}{l}\text { Number of direct reciprocal } \\
\text { relationships }\end{array}$ & $\begin{array}{c}-0.239 * \\
(0.133) \\
\end{array}$ & $\begin{array}{c}-0.239^{*} \\
(0.133) \\
\end{array}$ & $\begin{array}{c}0.055 \\
(0.060) \\
\end{array}$ & $\begin{array}{c}0.056 \\
(0.060) \\
\end{array}$ & $\begin{array}{c}0.028 \\
(0.073) \\
\end{array}$ & $\begin{array}{c}0.033 \\
(0.073) \\
\end{array}$ & $\begin{array}{l}-0.118 \\
(0.105) \\
\end{array}$ & $\begin{array}{l}-0.130 \\
(0.106) \\
\end{array}$ \\
\hline $\mathrm{N}$ & 153 & 153 & 782 & 782 & 523 & 523 & 431 & 428 \\
\hline
\end{tabular}

Unstandardized coefficients (standard errors)

Levels of Significance: $* \leq 0.1 ; * * \leq 0.05 ; * * * \leq 0.01$. 